\title{
Research on the Application of Financial Non-performing Assets Appraisal Based on Comprehensive Factor Analysis Method
}

\author{
Nanyun Xiao ${ }^{1, \mathrm{a}}$, Yan $\mathrm{Xu}^{1, \mathrm{~b}^{*}}$, Hongcheng Duan ${ }^{1, \mathrm{c}}$ \\ ${ }^{1}$ Harbin Finance University, Department of Accounting, Harbin, Heilongjiang, China
}

\begin{abstract}
The wanton growth of non-performing financial assets is fatal to the entire financial industry. Based on the research background, significance and content of financial non-performing assets, this paper first expounds the concept, classification and formation reasons of financial non-performing assets; secondly, it enumerates the common methods of financial non-performing assets appraisal in China; then, the method is applied to an actual case; finally, this paper analyzes the application of the method in the evaluation of nonperforming financial assets, and summarizes the full text. The research shows that: when the problems of incomplete debtor information, complex causes, involving a large number of related parties and related assets make it difficult to carry out the evaluation work, the comprehensive factor analysis method provides more possibilities.
\end{abstract}

\section{Introduction}

According to the statistics of CBRC, the scale of nonperforming financial assets in China is large, with the balance of non-performing loans increasing from 1705.7 billion yuan in 2017 to 241.5 billion yuan in 2019 , an increase of $41.50 \%$, and the non-performing loan rate from $1.74 \%$ in 2017 to $1.86 \%$ in 2019 . In the speech above, by the end of 2020, China's banking industry has disposed of 3.02 trillion yuan of non-performing assets. At present, the balance of non-performing loans is 3.5 trillion yuan, and the non-performing loan rate is $1.92 \%$.

In the market of financial non-performing assets, the non-performing assets of banks are the most common, which means that the disposal of bad assets plays a crucial role in the profitability of banking institutions. According to Bishnu Prasad Bhattarai in the latest research report

《Effects of non-performance load on profitability of commercial banks in Nepal》 [1], it is found that there is a significant negative correlation between NPLs and net asset return. Therefore, it is very important to evaluate the non-performing assets reasonably. However, due to the complex reasons for the formation of non-performing financial assets and unclear ownership, the development of NPF assessment business is more complex than the general asset appraisal business.

In recent years, the China Asset Appraisal Association and the four major asset management companies have summarized a relatively complete financial nonperforming asset method system based on hypothesis clearing algorithm, cash flow debt repayment method, comprehensive factor analysis method and transaction case comparison method [2], but it is affected by various factors in the actual appraisal business. It leads to many unpredictable problems in the application of each evaluation method.

\section{Non-performing financial assets appraisal and comprehensive factor analysis Method}

\subsection{Concept of non-performing financial assets}

First of all, we must make clear what the concept of financial non-performing assets is. In a broad sense, financial non-performing assets refer to the assets that are not in good operating conditions, cannot bring benefits in time, and difficult to recover on time. Among them, nonperforming assets are the most common. In addition, it also includes the non-performing assets of government, securities, trust, insurance and other non-banking institutions. In the 《Guidance on the evaluation of nonperforming financial assets 》newly revised by China Asset Appraisal Association in 2017, Article 2 of the general provisions specifies that the non-performing financial assets mentioned in the guidance refer to the sub-prime, suspicious and loss loans held by banks, the non-performing financial claims acquired or taken over by financial asset management companies, and the nonperforming financial claims held by other non-bank financial institutions [3].

* Corresponding author: Yan Xu1,b*724259289@qq.com 


\subsection{Comprehensive factor analysis method}

\subsubsection{Definition of comprehensive factor analysis}

Comprehensive factor analysis method refers to the analysis of the historical formation, loss reason, business operation status and liquidation data of loans based on reading the formation of all creditors' rights and debts relationship and the protection files of rights. It is necessary to understand the local macroeconomic environment and debt trading market in combination with the on-site investigation of professionals, and determine the main factors (loan time, purpose, amount, etc.) . Repayment source, repayment situation, overdue time, bank loan identification, loss reserve withdrawal, debtor reputation, future prospect prediction, local market environment, etc.) . And determine the degree of repayment that the creditor's right assets can obtain from the debtor or the related party responsible for the debt at a certain time point.

\subsubsection{Analysis of the procedure of financial non- performing assets appraisal based on comprehensive factor analysis method}

(1) First, through consulting the loan contract, mortgage contract, guarantee contract, legal documents and other information related to creditor's rights, the validity and limitation of litigation of the contract are analysed.

(2) Secondly, the paper analyses the repayment ability of the mortgage assets, first calculates the market value of the mortgage assets by using the appropriate evaluation method according to the characteristics of the mortgaged assets, and then calculates the net realizable value of the mortgage assets by considering the mandatory realization factors.

(3) Then, through the analysis and estimation of the solvency of the debtor and the guarantor, and when analysing the general solvency of the debtor and the guarantor, the solvency is estimated from the analysis of its current situation, operation status, income and other factors.

(4) The amount of the assets to be repaid is estimated by preserving the assets and other assets that are known to be available for repayment.

(5) The static recovery amount of the theory of claims is determined by the principle of lower than the total amount of claims by judging the repayment recovery value of mortgage assets, debtors, guarantors and other property clues.

(6) Considering the characteristics of disposal of nonperforming financial assets, the time to realize the recovery of the claims and the cost of clearing and collecting are estimated.

(7) The static recovery amount of the theory of creditor's rights minus the cost of clearing is the disposal price of the creditor's rights, that is, the liquidation value of the claims.

\section{Case analysis of non-performing financial assets appraisal}

\subsection{Case introduction}

Due to the needs of the company's operation and development, company f signed the "maximum amount financing agreement" with Bank $\mathrm{C}$, which is valid from December 2, 2014 to December 1, 2017. The agreement stipulates that bank $\mathrm{C}$ shall provide company $\mathrm{f}$ with a maximum amount of 8.25 million yuan of financing, and company $\mathrm{F}$ and relevant parties shall undertake joint and several liability guarantee and sign relevant subordinate contracts.

During the loan period, F Company returned the loan principal of 200000 yuan. After the sudden death of the guarantor Wang YL in February 2015, the loan was overdue. Bank $\mathrm{C}$ announced that the loan was due ahead of schedule. After the expiration of the contract, company $\mathrm{f}$ failed to repay the principal and interest as agreed in the contract.

\subsubsection{Debtor information}

F Company was established on March 16, 2010, with a registered capital of 2 million yuan, and its legal representative is Wang GQ. Its business scope: production or sales of auto parts; rubber products, hardware and electrical equipment, metal materials, etc.

\subsubsection{Basic information of the client}

Bank C was established on May 8, 1997, with a registered capital of RMB 3612251334 million, and its legal representative is Wang $h$. its business scope includes absorbing public deposits, issuing short-term, mediumterm and long-term loans, handling domestic settlement, handling bill discount, issuing financial bonds, etc.

\subsubsection{Debt liability related parties}

(1) Guarantor: Wang YL, male, legal representative of MS Company, has died;

(2) Sponsor: Wang Y, male.

(3) Sponsor: Zhang SG, male.

According to the inquiry of China executive information disclosure network, the guarantors Wang Y and Zhang SG have been listed in the national list of dishonest persons.

\subsection{Basic assessment items}

\subsubsection{Purpose of appraisal and analysis}

The purpose of this appraisal is to provide value reference for Bank $\mathrm{C}$ to dispose of non-performing financial assets. 


\subsubsection{The base date of debt value analysis}

The base date of this analysis is December 4, 2019. The reason is that the base date of debt value analysis is as close as possible to the date of economic behaviour realization, which is conducive to ensure that the analysis results effectively serve the analysis purpose.

\subsubsection{Types of creditor's rights value}

Considering that the purpose of this debt value analysis is to provide value reference for the client's transfer of nonperforming financial assets, the client needs to realize the non-performing financial assets in a short time, so it is determined that the liquidation value type is adopted in

Table1. Balance of credit principal and interest (as of the base date)

\begin{tabular}{|c|c|c|c|c|c|c|c|c|c|}
\hline \multirow{2}{*}{$\begin{array}{l}\text { Document } \\
\text { number }\end{array}$} & \multirow{2}{*}{$\begin{array}{l}\text { Credit } \\
\text { type }\end{array}$} & \multirow{2}{*}{$\begin{array}{l}\text { Credit } \\
\text { mode }\end{array}$} & \multirow{2}{*}{ Grant date } & \multirow{2}{*}{$\begin{array}{l}\text { Expire } \\
\text { date }\end{array}$} & \multirow{2}{*}{$\begin{array}{l}\text { Loan } \\
\text { amount (ten } \\
\text { thousand } \\
\text { yuan) }\end{array}$} & \multicolumn{4}{|c|}{ As of December 4, 2019 (10000 yuan) } \\
\hline & & & & & & $\begin{array}{c}\text { Principal } \\
\text { balance }\end{array}$ & $\begin{array}{l}\text { Owing } \\
\text { interest }\end{array}$ & $\begin{array}{c}\text { Advance } \\
\text { payment } \\
\text { cost }\end{array}$ & $\begin{array}{c}\text { Total } \\
\text { amount } \\
\text { of credit }\end{array}$ \\
\hline H001 & Loaning & $\begin{array}{c}\text { Mortgage } \\
+ \\
\text { guarantee }\end{array}$ & $\begin{array}{c}\text { December } \\
5,2014\end{array}$ & $\begin{array}{c}\text { December } \\
4,2016\end{array}$ & 610.00 & 590.00 & 380.83 & 5.77 & 976.61 \\
\hline
\end{tabular}

The scope of analysis is the solvency of debtors and related parties involved in the realization of F Company's creditor's rights.

According to the loan contract, mortgage contract, guarantee contract and corresponding legal documents, the scope of this analysis includes: the priority amount of the collateral, the debt paying ability of the borrower, the this project, and the liquidation value is the value of forced sale and forced realization, which is characterized by "forced sale and rapid realization" [4].

\subsubsection{The object and scope of debt value analysis}

The analysis object of the value of creditor's rights is all the creditor's rights of F Company involved in the disposal of non-performing financial assets. As of the base date, the balance of creditor's rights is 9.7661 million yuan (including 5.9 million yuan of principal, 3.883 million yuan of interest and 57700 yuan of prepaid expenses).( Table 1) debt paying ability of the guarantor and other assets available for debt paying. Among them:

(1) Collateral

No. D001 "maximum mortgage contract": the mortgaged property is a $531.65 \mathrm{M} 2$ commercial house owned by MS Company and located at No. 1 and No. 2 in the middle of Baoguang Avenue. See the following table

Table2. List of collateral

\begin{tabular}{|c|c|c|c|c|c|c|}
\hline $\begin{array}{l}\text { Owner of the } \\
\text { house }\end{array}$ & $\begin{array}{l}\text { Housing } \\
\text { ownership } \\
\text { certificate No }\end{array}$ & $\begin{array}{l}\text { Other rights } \\
\text { certificate No }\end{array}$ & $\begin{array}{l}\text { State owned land use } \\
\text { certificate No }\end{array}$ & Planned use & $\begin{array}{l}\text { Be located } \\
\text { (from the } \\
\text { effective } \\
\text { judgment) }\end{array}$ & $\begin{array}{l}\text { Built-up } \\
\text { area } \\
\left(\mathrm{m}^{2}\right)\end{array}$ \\
\hline $\begin{array}{l}\text { MS } \\
\text { company }\end{array}$ & $\begin{array}{l}\text { Real estate } \\
\text { right } \\
\text { certificate } \\
0001\end{array}$ & $\begin{array}{l}\text { Real estate } \\
\text { right } \\
\text { certificate } 000 \\
101\end{array}$ & $\begin{array}{l}\text { No. } 1 \text { (area of use right: } \\
518.03 \mathrm{~m} 2) \text { of XD } \\
\text { (household division in } \\
2006), \text { No. } 2 \text { of XD } \\
\text { national use }(2013) \text { (area of } \\
\text { use right: } 13.62 \mathrm{~m} 2)\end{array}$ & Business & $\begin{array}{l}\text { No. } 1 \text { and No. } 2 \text {, } \\
\text { middle section } \\
\text { of Baoguang } \\
\text { Avenue }\end{array}$ & 531.65 \\
\hline
\end{tabular}

Physical situation: according to the on-site investigation, except for No. 2 vacant, the rest are rented out.

(2) Seizure of assets C.

The collateral has been waiting to be sealed up by bank

\section{(3) Guarantee situation}

Maximum amount guarantee contract (No. D0010201, No. D0010202 and No. D0010203): the guarantors Wang YL, Wang Y and Zhang SG are a series of creditor's rights formed by Bank C's granting credit to the debtor of the main contract from December 5, 2014 to December 4, 2017, providing joint and several liability guarantee within the maximum amount of 8.25 million yuan.

for details( Table 2): 
and No. 2 in the middle of Baoguang Avenue, with a building area of $531.65 \mathrm{~m} 2$, is a series of creditor's rights formed by Bank C's granting credit to the principal debtor from December 2, 2014 to December 1, 2017, It also provides a joint and several liability guarantee with a maximum amount of 8.25 million yuan, covering the principal and interest (including compound interest and penalty interest) of the credit, as well as related expenses, liquidated damages, compensation and all expenses incurred for the realization of the main creditor's rights.

On December 5, 2014, Bank C and Wang YL, Wang Y and Zhang SG signed 《The maximum amount guarantee contract》 No.D0010201,D0010202 and D0010203, which agreed that the above guarantors were a series of creditor's rights of company f from December 5, 2014 to December 4, 2017 due to Bank C's granting credit to the debtor of the main contract, and provided joint and several liability guarantee with the maximum amount of 8.25 million yuan, The scope of guarantee includes credit principal and interest (including compound interest and penalty interest) as well as related expenses, liquidated damages, compensation and all expenses incurred for realizing the main creditor's right.

On the same day, Bank $\mathrm{C}$ and company f signed the 《Loan contract》 No. h001. Bank C provided Company $\mathrm{F}$ with a working capital loan of 6.1 million yuan. The purpose of the loan was to purchase raw materials. The loan term was 2 years, i.e. from December 5, 2014 to December 4, 2016. The loan interest rate was $65 \%$ higher than the benchmark interest rate of the same grade loan announced by the people's Bank of China.

After the above contract was signed, Bank $\mathrm{C}$ issued the loan according to the contract, and company f returned the loan principal of 200000 yuan during the loan period. The loan was overdue due to Wang YL's sudden death in February 2015. Bank C announced that the loan was due ahead of schedule. After the contract expired, company $\mathrm{f}$ failed to repay the principal and interest as agreed in the contract.

As of December 4, 2019, the balance of creditor's rights is 9.7661 million yuan (including 5.9 million yuan of principal, 3.8083 million yuan of interest and 57700 yuan of advance payment).

On the premise that the intention of both parties is true, the signing of the corresponding contract is in accordance with the law. According to the corresponding loan withdrawal certificate, Bank $\mathrm{C}$ has actually issued the loan to the borrower according to the above contract.

According to the (2016) C001 No. 1 《Civil judgment》 issued by X District People's Court of C City, the creditor's right was established.

\subsubsection{The amount recoverable through the collateral}

(1) For the basic information of the collateral, please refer to "analysis object and scope of the value of creditor's rights".

(2) Judgment on the market value of collateral

At present, the common analysis methods in the industry include market method, income method, cost method, hypothetical development method, etc. as the collateral is mainly used for leasing, the future expected income, income period, discount rate and other parameters can be estimated, so the income method is used to evaluate the collateral.

The income method is a method to predict the future expected income of the analysis object, and use the capitalization rate (or discount rate) to discount the future expected income to obtain the evaluation value of the analysis object .

Through analysis and calculation, the market value of commercial housing mortgage is 8.93 million yuan. See the following table for details:

(3) Auction realization coefficient

The mortgage is the mortgage asset involved in the non-performing financial claims. In the above market value judgment, according to the relevant requirements and regulations of the appraisal, the regional factors and individual factors of the property have been considered in the market value calculation. The analysis of the auction realization coefficient of the collateral mainly refers to: (1) statistics of the realization rate of similar assets sold by judicial auction and stock exchange; (2) The analysis of transaction activity of the asset in the market environment; (3) The types of assets, physical status, ownership, regional market and other factors; (4) Market supply and demand data and investment data of assets. The factors affecting the realization of the collateral are as follows (Table 3):

Table3. Detailed list of market value of collateral calculated by income method

\begin{tabular}{|c|c|c|c|c|c|c|c|}
\hline $\begin{array}{l}\text { Owner of the } \\
\text { house }\end{array}$ & $\begin{array}{l}\text { Housing } \\
\text { ownership } \\
\text { certificate No }\end{array}$ & $\begin{array}{l}\text { Other rights } \\
\text { certificate No }\end{array}$ & Planned use & Be located & $\begin{array}{l}\text { built-up area } \\
\left(\mathrm{m}^{2}\right)\end{array}$ & $\begin{array}{l}\text { Market unit } \\
\text { price } \\
\left(\text { yuan } / \mathrm{m}^{2}\right)\end{array}$ & $\begin{array}{l}\text { Market value } \\
\text { (10000 yuan) }\end{array}$ \\
\hline MS company & $\begin{array}{l}\text { Real estate } \\
\text { right } \\
\text { certificate } \\
0001\end{array}$ & $\begin{array}{l}\text { Real estate } \\
\text { right } \\
\text { certificate } \\
000101\end{array}$ & Business & $\begin{array}{l}\text { No.1 and } \\
\text { No. } 2 \text {, middle } \\
\text { section of } \\
\text { Baoguang } \\
\text { Avenue }\end{array}$ & 531.65 & 16800 & 893 \\
\hline
\end{tabular}

(1) The commercial mortgage house has a large area, high total price and limited potential customers; (2) Except for No. 2 vacant, the rest are leased out of the world. The specific lease condition is not clear, which may have an impact on subsequent disposal; (3) The collateral is located in the old city, and the regional living facilities are relatively mature, but it is difficult to promote the disposal due to the influence of MS company in debt and litigation.

In summary, referring to the realization rate of about $70 \%$ of general commercial houses in zone $\mathrm{x}$, the auction realization coefficient of the general commercial houses 
in zone $\mathrm{x}$ is comprehensively determined according to $70 \%$ in this calculation.

(4) Auction closing price

Auction closing price $=$ market value $\times$ Auction realization coefficient, Commercial and residential land $==893 \times 70 \% \approx 625$ ( Ten thousand yuan)

(5) Disposal related cost estimation

Bank C has filed a lawsuit and won the lawsuit on this claim and sealed up the mortgaged property. At present, the execution of the mortgage has been completed and the relevant expenses have been paid, so it will not be considered this time. According to relevant regulations, the total cost of this disposal is about 94500 yuan, as follows:

(1) According to the 《Measures for payment of litigation expenses》 No. 481 of the State Council order, the compulsory application fee is 58700 yuan; (2) According to the 《Provisions of the Supreme People's Court on some issues concerning the online judicial auction of the people's Court 》(FSI [2016] No. 18), if the people's court disposes the property by auction, it shall adopt the online judicial auction method. At present, the court system comprehensively promotes online judicial auction. According to the current regulations, the online auction platform does not charge the auction service fee, so the auction service fee is not calculated this time; (3) According to the relevant provisions of judicial appraisal fees, the judicial appraisal fee is 35900 yuan.

(6) Taxes related to the transfer of collateral

Now the judicial auction has promoted the network auction in an all-round way. The tax involved in the announcement of online judicial auction in the implementation is borne by the buyer, so the tax involved in the transfer of the mortgaged goods is no longer considered.

(7) Recoverable value of collateral

In summary, namely: According to the above calculation, the recoverable amount of the mortgaged property is about 6.16 million yuan, which cannot cover the balance of the debt of 9.7661 million yuan, that is, the amount of priority compensation obtained through the collateral is 6.16 million yuan, and the rest 3.661 million yuan is regarded as general compensation.

Recoverable value of collateral $=(4)-(5)-(6)$

$=625-9.45-0 \approx 616$ ( Ten thousand yuan)

According to the above calculation, the recoverable amount of the collateral is about 6.16 million yuan, which cannot cover the balance of the creditor's rights of 9.7661 million yuan. That is to say, the amount of priority compensation obtained through the collateral is 6.16 million yuan, and the remaining 3.0661 million yuan is regarded as general compensation.

\subsubsection{Recoverable amount through Borrower}

Borrower F Company is mainly engaged in the production and sale of auto parts, rubber products, etc., and has now stopped business.

No property right certificate has been obtained in the factory area under the name of the company. According to the operator, the land price of the borrower's factory area has not been paid. Under the influence of the company's stop of operation and the death of the actual controller Wang YL, the plant cannot be disposed at this stage.

The machinery and equipment under the company's name have been sealed up by MT commercial bank, with the subject matter of 8.3 million yuan. Considering that the company has stopped operation and the equipment maintenance management is lagging behind, the mechanical equipment is special equipment, and it is difficult to realize the disposal; At the same time, the mechanical equipment has been sealed by MT commercial bank, with the larger subject matter involved. It is expected that the first inspection creditor's rights cannot be repaid after the disposal and Realization of the mechanical equipment. The comprehensive analysis of Bank $\mathrm{C}$ is not likely to be compensated.

In summary, the recoverable amount through the borrower is 0 .

\subsubsection{Recoverable amount through guarantor}

The natural person guarantor Wang YL (dead), Wang Y and Zhang SG have not found the debt repayment assets for the time being. The probability of obtaining general repayment through the above surety is relatively small, and it is estimated that it is 0 .

\subsubsection{The recoverable amount of the debt repayment assets is learned through other means}

Other assets known to be available for repayment herein include sealed non mortgaged assets, non-mortgaged assets adjudicated for debt repayment or assets of nondirect debtors who are willing to provide to creditors for other reasons to pay debts, etc.

After on-site investigation and understanding with the bank, no other available assets for repayment have been found.

\subsubsection{Static recovery value of claims}

The sum of the above 2-5 recoverable amount is 6.16 million yuan. Since the sum of the recoverable amount is less than the balance of the creditor's rights, the static recovery value of the claim is 6.16 million yuan.

\subsubsection{Determination of liquidation value of claims}

(1) The analysis determines that the recovery period of the claim is 2 years, for the reasons as follows:

(1) Bank $C$ has filed a lawsuit against the claim and won the lawsuit. However, in the process of execution, the mortgagor MS Company has many debts, and the property is sealed by many courts, and cannot be disposed and realized temporarily. The execution has been completed, and the subsequent settlement period is long; (2) Except for vacant No. 2, the mortgaged goods are leased out of the world, but the lease condition is not clear, which may have an impact on subsequent disposal; (3) 
No property available for execution is found under the name of the borrower and the guarantor, so it is difficult to recover the claims and takes a long time.

(2) Referring to the average level of the cost of clearing and collecting similar non-performing financial assets, the annual settlement cost is estimated at $12 \%$ of the calculated value of the creditor's rights.

(3) If above, the settlement value of the claim is 616 , calculated according to the two-year disposal cycle and the cost rate of settlement is estimated at $12 \% \div(1+12 \%$ $\times 2$ ) About RMB 4970000 .

According to the above analysis, the liquidation value of the creditor's rights of RMB 9766100 of company $f$ involved in the disposal of financial non-performing assets by Bank $\mathrm{C}$ as of the benchmark date is RMB 4.97 million, in words, RMB four million nine hundred seventy thousand, the principal recovery rate being $84.24 \%$, and the principal and interest recovery rate of $50.89 \%$.

\subsection{Analysis and evaluation conclusions and special notes}

\subsubsection{Evaluation conclusion}

As of the base date, the liquidation value of the 9.7661 million yuan creditor's rights of company $\mathrm{f}$ involved in the disposal of non-performing financial assets by Bank $\mathrm{C}$ is 4.97 million yuan, in words 4.99 million yuan.

\subsubsection{Special notes}

(1) Statement on validity of evaluation conclusion. The above evaluation conclusion is based on all the information provided by both parties. The client, the debtor and the related parties of the debt liability shall be legally responsible for the authenticity, accuracy, legality and integrity of the information provided by them, and the debtor shall be responsible for the security and integrity of the debt assets; the appraisal institution and professionals are responsible for the analysis report referring to the relevant provisions in the 《Guidance on the appraisal of non performing financial assets $\rangle$.

(2) Statement of influencing factors of evaluation conclusion. (1) if the debtor and the related party of debt liability have other assets or other repayment sources, the analysis conclusion will be lower than the objective value of the creditor's right; if the debtor has other debts, the analysis result may be higher than the objective value of the claim. (2)If the debtor and the related party of debt liability intend to conceal assets and falsely increase liabilities, the client shall state that it reserves the right to further recover the remaining creditor's rights, otherwise, the company and professionals shall not be liable for the consequences arising therefrom. (3) Except for No. 2 vacant, the rest of the mortgaged commercial houses are rented out, but the specific leasing status is unknown, so this analysis cannot consider the impact of leasing factors on the value of the mortgaged property. (4)According to the information provided by the client, the two commercial houses mortgaged are the same house ownership certificate (xfqzjzz No. 0001). Because the client is unable to provide the household area table of the two houses, this calculation is based on the area of the house ownership certificate and with reference to the use of "commercial land" and "the termination date of land use right on April 14, 2044" of the two land use certificates.

(3) Statement on timeliness of evaluation conclusion. The analysis result of the value of the creditor's rights is the analysis opinion on December 4, 2019, which is only valid under the premise set by the analysis opinion. When the assumptions and analysis conditions change, the investigation and analysis result will be invalid; The validity period of the general assessment conclusion is one year, from December 4, 2019 to December 3, 2020.

\section{Conclusions}

The idea of the comprehensive factor analysis method is to determine the extent to which the creditor can be compensated by analysing the debt paying ability of the relevant economic entities such as the mortgage, the borrower and the guarantor. When analysing the value of the financial non-performing assets, the comprehensive factor analysis method is obviously the best choice when the debtor information cannot meet the application conditions of the hypothetical clearing algorithm. On the one hand, the method does not fully consider the impact of the company's financial situation on the assessed value, but it is based on the existing known assets of the enterprise and related parties to analyse the debt repayment of creditors, which is feasible both in theory and practice.

\section{Acknowledgment}

Project source : (1) 2020 Heilongjiang Provincial Universities Basic Scientific Research Business Expenses Scientific Research Project, No. 2020-KYYWF-010; (2)2018 Heilongjiang Provincial Universities Basic Scientific Research Business Expenses Scientific Research Project, No. 2018-KYYWF-E018

\section{References}

1. BHATTARAI B P. Effects of Non-performing Loan on Profitability of Commercial Banks in Nepal [J]. European Business \& Management, 2020, 6(6).

2. Improve the asset appraisal system to ensure the security of financial market [N]. 2019-11-27 (008)

3. Cao Jianping, Wang Shujun. A case of debt value analysis by comprehensive factor analysis $[\mathrm{J}]$. China asset appraisal, 2012, (02): 40-43

4. Cui Jin, Yin Xia. Revising the guidance on the evaluation of non performing financial assets to help national financial security $[\mathrm{J}]$. China asset raisal, 2017, (11): 9-10 